\title{
Long-term changes in rainfed olive production, rainfall and farmer's income in Bailén (Jaén, Spain)
}

\author{
Jesús Rodrigo-Comino ${ }^{1,2}$ - José María Senciales-González ${ }^{3} \cdot$ Yang Yu $^{4,5} \cdot$ Luca Salvati $^{6}$. Antonio Giménez-Morera ${ }^{7}$. \\ Artemi Cerdà
}

Received: 18 November 2020 / Accepted: 24 May 2021 / Published online: 18 June 2021

(c) The Author(s) 2021

\begin{abstract}
Economic, social, and climatic conditions affect agricultural production. Those changes are relevant to the rainfed agricultural areas of the Mediterranean Belt, including Spain - the largest producer of olive oil in the world. However, little is known about the effect of the climate on olive production and farmer income. In this study, the correlation between changes in rainfall and total olive production was examined using a long-term dataset (28 years) on conventional rainfed production and tillage soil management. The dataset focused on different olive groves in the municipality of Bailén (Jaén, Andalusia) that have been owned by the same farmer since 1966. The province of Jaén is the region of Spain with the highest production of olive oil and the largest area of olive groves. The data included annual rainfall, production per plot and the price of olives. After calculating missing data to complete the rainfall series, pairwise correlation analysis with nonparametric Spearman's rank coefficients and principal component analysis were used to process the data. The results showed that higher production coincided with increased rainfall during August and December. Therefore, we concluded that the impact of rainfall on olive production is variable and depends on drought intensity and the monthly rainfall distribution. An economic study showed that farmer income was highly dependent on the seasonal distribution of the rainfall among other factors such as the price of olives. Farmer income was low during drought periods, indicating that rainfed agriculture is perceived by farmers as unsustainable due to the resulting highly variable income. This study could help to prevent risks to food security in the future. We recognise that other key factors have also been important influences on the fluctuations in olive production over the years, such as soil properties and plant status. However, cultivating olives without irrigation-depending only on the total rainfall amount and rainfall intensity to supply all of the water consumed by the plants-is very risky too. This research demonstrates that the subsistence of Mediterranean rainfed olive farmers can be highly dependent on the rainfall conditions.
\end{abstract}

Keywords Farmers $\cdot$ Rainfall $\cdot$ Olive groves $\cdot$ Economy $\cdot$ Production

Responsible Editor: Elena Xoplaki.

Jesús Rodrigo-Comino

jesusrc@ugr.es

1 Departamento de Análisis Geográfico Regional y Geografía Física, Facultad de Filosofía y Letras, Campus Universitario de Cartuja, Universidad de Granada, 18071 Granada, Spain

2 Physical Geography, Trier University, 54286 Trier, Germany

3 Department of Geography, University of Málaga, 29071 Málaga, Spain

4 School of Soil and Water Conservation, Beijing Forestry University, Qinghua East Road 35, Beijing 100083, People's Republic of China
5 Jixian National Forest Ecosystem Research Network Station, CNERN, Beijing Forestry University, Beijing 100083, People's Republic of China

6 Department of Economics and Law, University of Macerata, Via Armaroli 43, 62100 Macerata, Italy

7 Departamento de Economia y Ciencias Sociales, Universitat Politècnica de València, Cami de Vera S/N, S46022 Valencia, Spain

8 Soil Erosion and Degradation Research Group, Department of Geography, University of Valencia, 46010 Valencia, Spain 


\section{Introduction}

The olive (Olea europea) is one of the oldest domesticated plants. Olive grove cultivation has been linked to human societal development throughout history. As Cicatelli et al. (2013) mentioned, the olive tree was probably the first domesticated tree. Olive domestication first occurred approximately 5500 years ago, when the earliest eastern civilisations arose. tree domestication has long informed the image of the Mediterranean region, even given its varied and harmonious landscapes (Delgado et al. 2013). Scheidel and Krausmann (2011) affirmed that numerous factors (biological, climatic, topographical and pedological) affect the natural development of olives and its expansion as a crop (e.g. the development of new technologies, market trends, and public tastes) in the middle latitudes. The total area of olive grove plantations has increased, particularly in southern Spain and specifically in Andalusia. Studies have utilised various statistical sources and analytical techniques to quantify this drastic expansion of olive cultivation and the consequences for this region of Spain of the specific soil treatment and land management activities needed for olive cultivation (Amate et al. 2013; Infante-Amate and de Molina 2013; Villalobos and Mateos 1995). It is well known that most of the arable land in Andalusia, and even areas of this region that do not have soils that are highly suited to farming (e.g. mountainous areas or floodplains), is occupied by olive groves. The Picual cultivar is particularly common, but others such as Royal, Picuda and Cornezuelo are also found in this region. Similar landscapes full of olive groves have developed around the Mediterranean Basin; indeed, it is considered the traditional landscape of the Mediterranean. Some authors claim that the Mediterranean Belt is where olives grow best (Braudel 1996).

Within Spain, the largest producer of olive oil in the world, Jaén Province produces about $600,000 \mathrm{Mg}$ of olives on more than 66 million olive trees (covering 550,000 ha), thus contributing $20 \%$ of the world's olive oil production (Regional Government of Andalusia). This corresponds to an economic value of $300 \mathrm{M} €$, so olive production is the economic engine for this region. Some authors point out that although Spanish state support mechanisms for olive farmers have gradually been lost, an olive grove model created and popularised by the Common Agricultural Policy can still be observed (Perujo Villanueva and Colombo 2017; Rocamora-Montiel et al. 2014). This intensive structure results in groves with 200-300 olive trees per ha, or up to 450 if they are irrigated. Recently, superintensive olive plantations with 2000 trees ha ${ }^{-1}$ have been created. This increasing landscape fragmentation has large financial benefits for large state owners of plantations, but not for local farmers who did not know how to take advantage of this situation because they manage small properties and lack information on the very bureaucratic system of subsidies (Areal and Riesgo 2014; Emmanouilides et al. 2013). Specifically, among the various olive groves of Jaén, there are a range of productive capacities $\left(500-15,000 \mathrm{~kg} / \mathrm{ha}^{-1}\right)$, and producers cannot set their sales prices in the global market (Jiménez et al. 2002).

Generally, natural resources such as the soil or water are not used efficiently during the olive production process (Taguas and Gómez 2015; Zema et al. 2015), there are new competitors with lower prices, and the age profile of smallholding farmers is increasing because the number of young people that wish to work on smallholdings is dwindling (Martínez and Simón 2011). This situation results in negative effects on the environment, such as increased erosion rates, water pollution, and losses of biodiversity and productivity (Vanwalleghem et al. 2011; Kairis et al. 2013; Rodrigo-Comino et al. 2018a, b). However, despite these difficulties, the ownership of an olive grove continues to provide a degree of social prestige and a good patrimonial refuge for Andalusian rural society (Rodrigo-Comino et al. 2020b). Furthermore, olive cultivation is considered viable if the current price of olive oil is taken into account and considering the numerous applications of olive oil in the Mediterranean diet as well as its healthy properties (Gimeno et al. 2002; Marin et al. 2011; Kairis et al. 2015).

Given these considerations, one might ask: what are the factors that determine high olive production? Several researchers attribute the greatest weight to environmental factors such as crop variety, soil type and surface cover or topography, and to aspects of the human management of olive groves such as the degree of mechanisation and use of agrochemicals (Cerdà et al. 2021a; Karamesouti et al. 2015; López-Vicente and Álvarez 2018; Michalopoulos et al. 2020; Yu et al. 2016). But what about the olive farmers? According to the farmers, the key factor in olive production is rainfall. Moreover, they work daily on their land and have a deep knowledge of their groves. Furthermore, their experience allows them to become environmental experts if they are taught or well advised (Benites et al. 2005; Kosmas et al. 2016; Sastre et al. 2016), meaning that farmers can advise on land management and environmentally friendly policies. This is something that seems to have recently been discovered by politicians and scientists.

When olives are cultivated under rainfed conditions, olive growth is highly dependent on the climatic conditions present (Scarascia et al. 2006). Thus, given that the olive tree is a masting plant, it is not surprising that alternating good and bad harvests of such olives are observed, as this is inevitable for such a traditional system with a limited capacity to increase production (Benmehaia et al. 2020; Naredo 1983). 
Therefore, the starting hypothesis in the work reported in the present paper was that rainfall determines olive production under Mediterranean climatic conditions (Rodrigo-Comino et al. 2021; Salvati et al. 2012). Some recent studies of olive groves have correlated bioclimatic (Oteros et al. 2014), geomorphological (Taguas et al. 2015), hydrological (Salmoral et al. 2017) or economic (Emmanouilides et al. 2013) variables with olive production to explain this fact. Modelling investigations aiming to provide future projections at large scales have recently become very common, and seem to be very accurate (e.g. Incerti et al. 2007; Ponti et al. 2014; Tanasijevic et al. 2014; Fraga et al. 2019, 2020; Arenas-Castro et al. 2020). Also, the impacts of the climate and global warming on the production of other rainfed crops such as grapevines have been estimated through diverse techniques (Ashenfelter and Storchmann 2010; Storchmann 2005; Urhausen et al. 2011). However, recent research focusing on longterm ( $>25$ years) in-situ rainfall monitoring data obtained with rain gauges (installed on private olive plantations) and production data obtained directly from farmers and cooperatives is scarce. Even the validation of such data and results obtained by farmers is rare. While the monitoring of production and climate data has recently been implemented, old and long-term datasets-which are very valuable for understanding changes in production-are unusual.

In the research described in this paper, the main goal was to characterise the production of olive groves under a rainfed production system in Andalusia and to analyze the correlation between rainfall data (a tracer of climate variability and change) and the production of olives. This research focused on plots with olive trees in the municipality of Bailén (Jaén). To achieve the goal of the study, two long-term datasets (on rainfall and production) were collected by a farmer for two different periods: 1966-1977 and 1991-2007. The agricultural fields of interest utilised a rainfed system and manure was employed as a fertiliser. The intention was to quantify the probability that olive production increases or decreases with fluctuations in rainfall during specific months. To reinforce and validate the rainfall series and to fill the gaps in that series due to a lack of data collection by farmers, data from nearby climate stations were also collected. We hypothesised that changes in the price per year paid to the farmers by their olives could demonstrate the difficulties that traditional farmers face when their olive production depends on the occurrence of rain events at specific times of the year. The main challenge could be the difficulty involved in predicting the annual pattern of variation in the climate. The main concern for olive producers is the monthly rainfall distribution, and so this distribution was researched in the present work.

\section{Materials and methods}

\section{Study area}

The selected study area corresponds to a group of cultivated olive tree plots in the municipality of Bailén (Comarca de la Campiña, Jaén Province, Andalusia, Spain). This municipality is located in the NW of Jaén Province, and borders the municipalities of Baños de la Encina, Guarromán, Linares, Jabalquinto, Espelúy and Villanueva de la Reina. It is located between 300 and $400 \mathrm{~m}$ a.s.l. in the north of the physiographic unit of the Guadalquivir countryside and south of Sierra Morena, and encompasses an area of $320 \mathrm{~km}^{2}$ (Fig. 1). The average temperature in Bailén is $17.4{ }^{\circ} \mathrm{C}$ and its annual precipitation averages $474 \mathrm{~mm}$.

Historically (since the 1980s), Bailén was an important economic centre within Jaén for two reasons: (1) national highway 323 through Bailén to the mountain pass of Despeñaperros provided the best access route to Madrid, and (2) its high-clay soils represent natural resources for the brick and ceramic industry. However, the subsequent construction of another road to and from Madrid that avoids Bailén and the current economic crisis linked to construction have diminished the economic importance of Bailén. Nevertheless, Bailén has a rururban character due to its demographic development since the 1980s. Nowadays, the urban and rural roots of the local inhabitants are deeply entrenched due to the development of the brick and ceramic industry and the importance of olive grove cultivation in this region.

The parcels within Bailén of interest in this study (covering $4.6 \mathrm{ha}$ ) belong to one owner and are distributed throughout the municipality. The plots contain 384 olive trees of the Picual variety. Plot data, including surface area, exact location and some other characteristics are registered an application called SIGPAC viewer (http://sigpac.mapama.gob.es/fega/visor/) managed by the Junta de Andalusia. Selected plot data are presented in Table 1 and Fig. 2. Pruning is usually carried out in January-February each year after the olives have been harvested. As the harvested olives are intended for oil production, pruning can last until March.

\section{Data sources}

\section{Olive production}

Two different data series were used in this study. A total of 28 years of olive production and euros per $\mathrm{kg}$ (converted from pesetas, the currency of Spain between 1868 and 


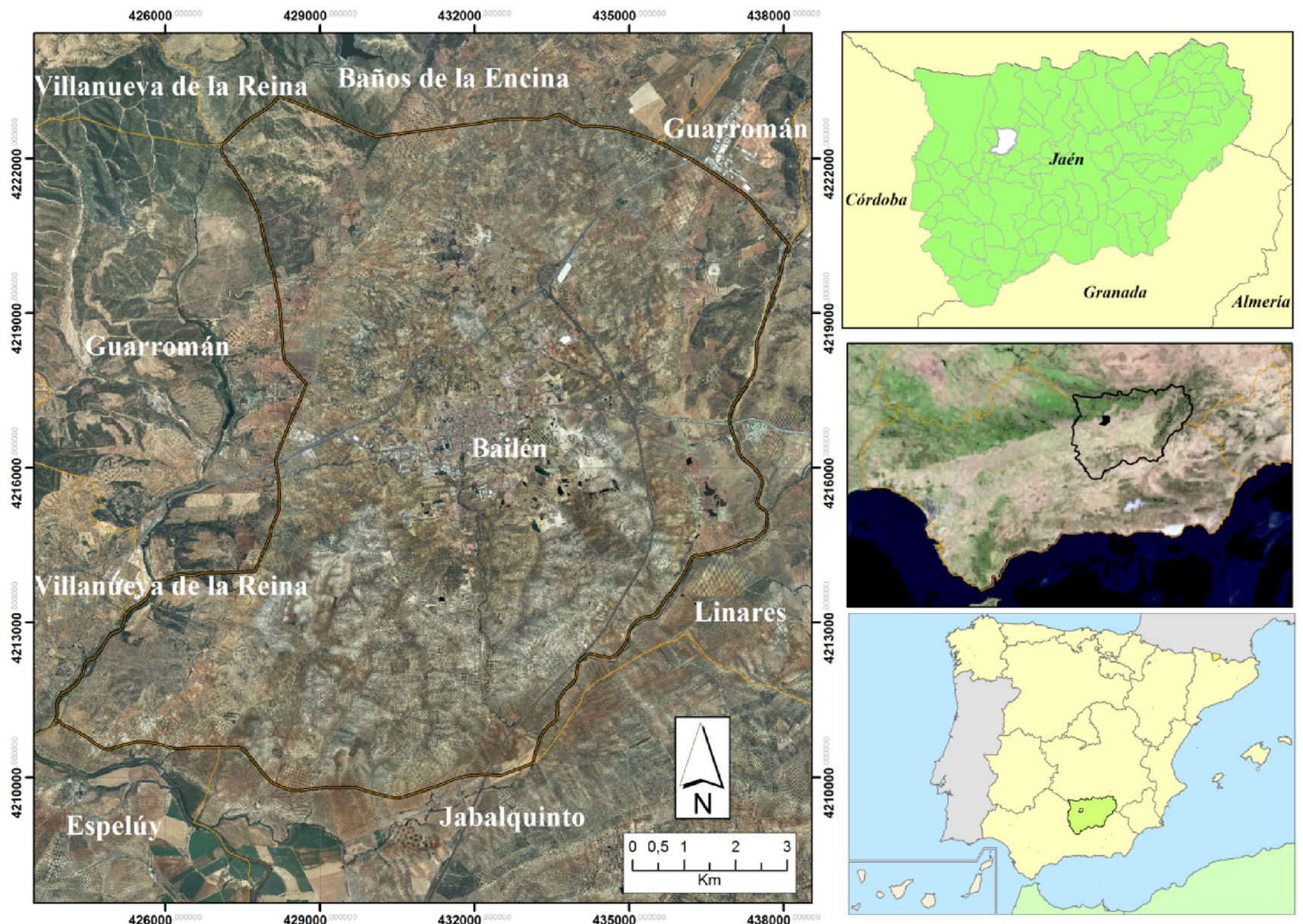

Fig. 1 Location of the municipality of Bailén

2002) data were collected, covering two different periods: 1966-1977 and 1991-2007. The data were quantified by the Agrarian Cooperative of Bailén when the farmer transported the harvested olives each year. The total olive production, measured in kilograms, was handwritten by the farmer's wife in a notebook (Fig. 3) and subsequently transferred to an Excel datasheet in 2013.

\section{Rainfall dataset and calculation of gaps}

Rainfall events occurring during the same month were grouped together to facilitate the statistical analysis. The data were obtained from AEMET (Spanish Meteorological Agency) weather stations of the María Bellido Institute (5281A) and from an approved rain gauge of the Agrarian Cooperative of Bailén, which provided the production records used in this work. However, there are more gaps in the official data series than in the private ones. Thus, in some cases where it was possible, data to fill the gaps in the data series were calculated to alleviate this situation
(CEOTMA 1996). Only the years with the least gaps in the data series were selected for the study. To calculate the gaps in the data series, reference data from the Úbeda and Linares stations handled by the IFAPA (Instituto de Formación Agraria y Pesquera de Andalusia; http://www. juntadeAndalusia.es/agriculturaypesca/ifapa/web) were used through the following equation (Aguilar et al. 2003):

$P_{A}=1 / n \times\left(\left(N_{a} / N_{b}\right) \times\left(N_{a} / N_{c}\right) \times P_{c}+\cdots\left(\left(N_{a} / N_{n}\right) \times P_{n}\right)\right)$,

where $P_{A}$ is the missing value from an AEMET station; $n$ represents the number of stations used as reference stations (preferably stations within the same physiographic unit as the AEMET station with the missing value); $N_{a}$ is the mean of the AEMET station with the missing value; $N_{b}, N_{c}$ and $N_{n}$ are the mean precipitation values for the reference stations $b, c$ and $n$ for the month of interest (i.e. when the missing value occurs); and, finally, $P_{b}, P_{c}$ and $P_{n}$ are the precipitation values from reference stations $b, c$ and $n$ during the month of interest. 
Table 1 Characteristics of the plots in the study area (retrieved using the SIGPAC application)

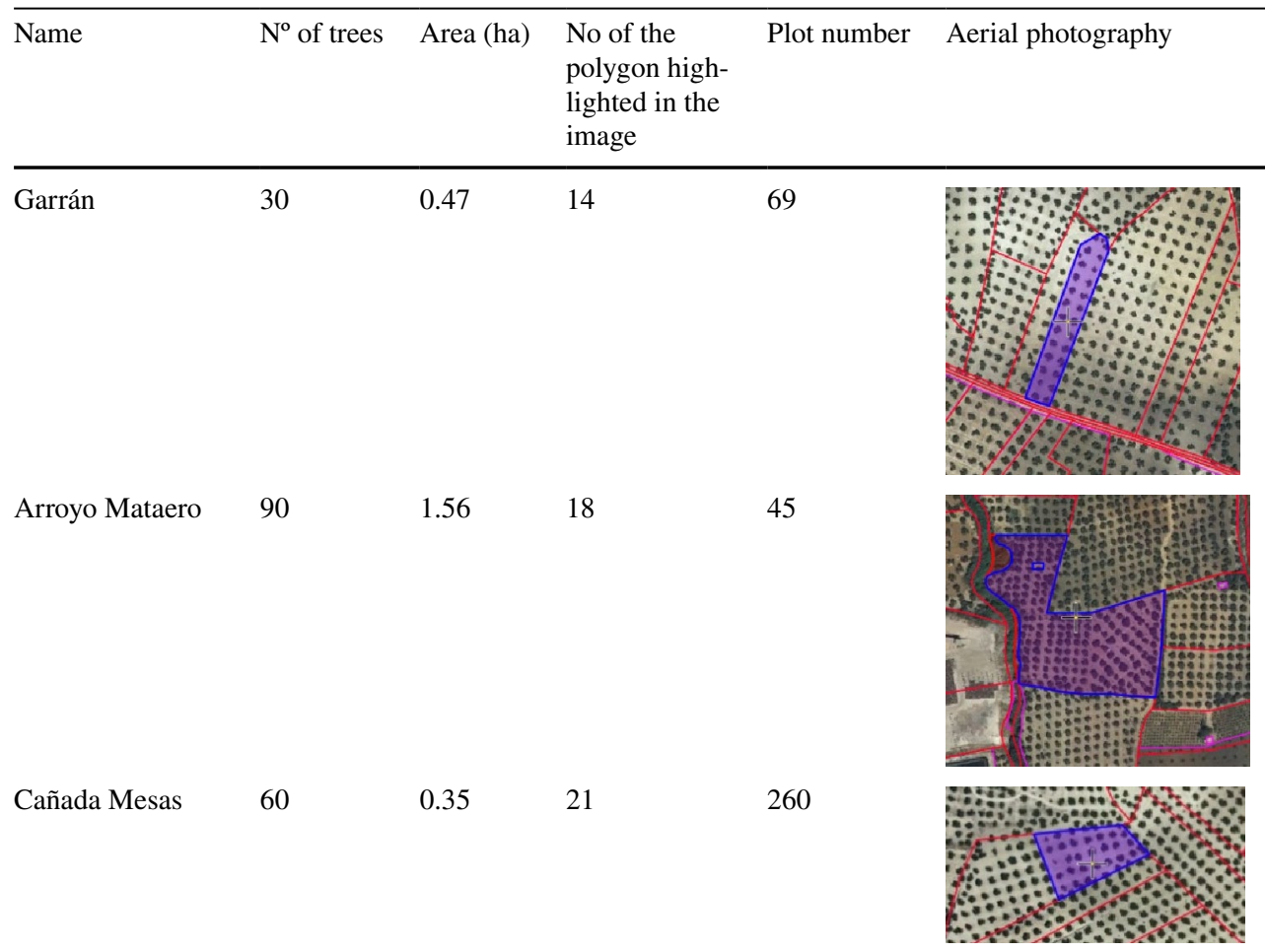

$\begin{array}{lllll}\text { Cuarterones } & 85 & 1.04 & 27 & 49\end{array}$

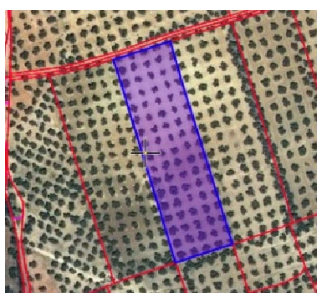

Pinos de Quevedo

$\begin{array}{lll}0.71 & 31 & 6\end{array}$

6

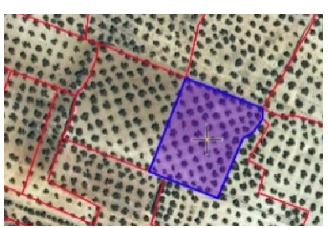

$\begin{array}{lllll}\text { Valdemolín } & 27 & 0.27 & 31 & 21 \\ \text { Valdemogín } & 16 & 0.23 & 31 & 68 \\ & & & & \\ \text { Total } & 384 & 4.64 & & \end{array}$

21

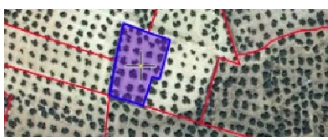

68

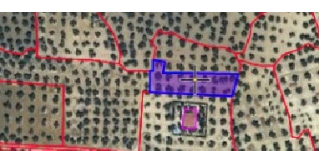

\section{Statistical analysis}

Arithmetic means, standard deviations, coefficients of variation and the maximum total values for the whole datasets were calculated. The results were then visualized in box plots showing the 5th and 95th percentiles, the mean and median values, and the range using SigmaPlot 12.0. To evaluate correlations between variables, pairwise correlations with Spearman's rank coefficients were examined using SPSS v.22 (IBM, USA), since the empirical data deviated from a normal distribution. Significant correlations were tested at the $p<0.05$ level. Finally, to detect 


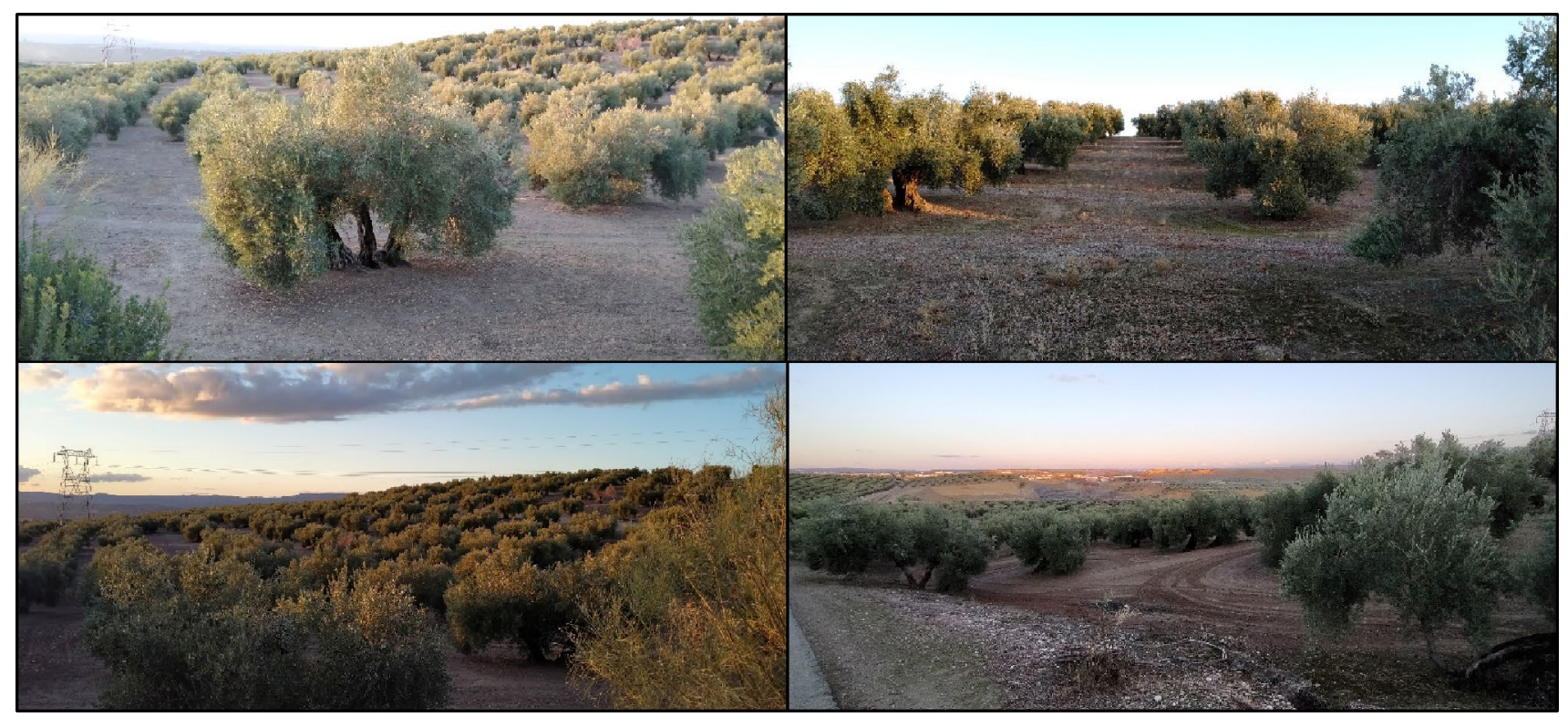

Fig. 2 Overview of the study area, showing olives and bare soils on gentle hill slopes. Photos were taken by Mr. Francisco Comino Oriola

Fig. 3 Photographs showing the notes taken by Rosa Oriola and Manuel Comino during the monitoring period

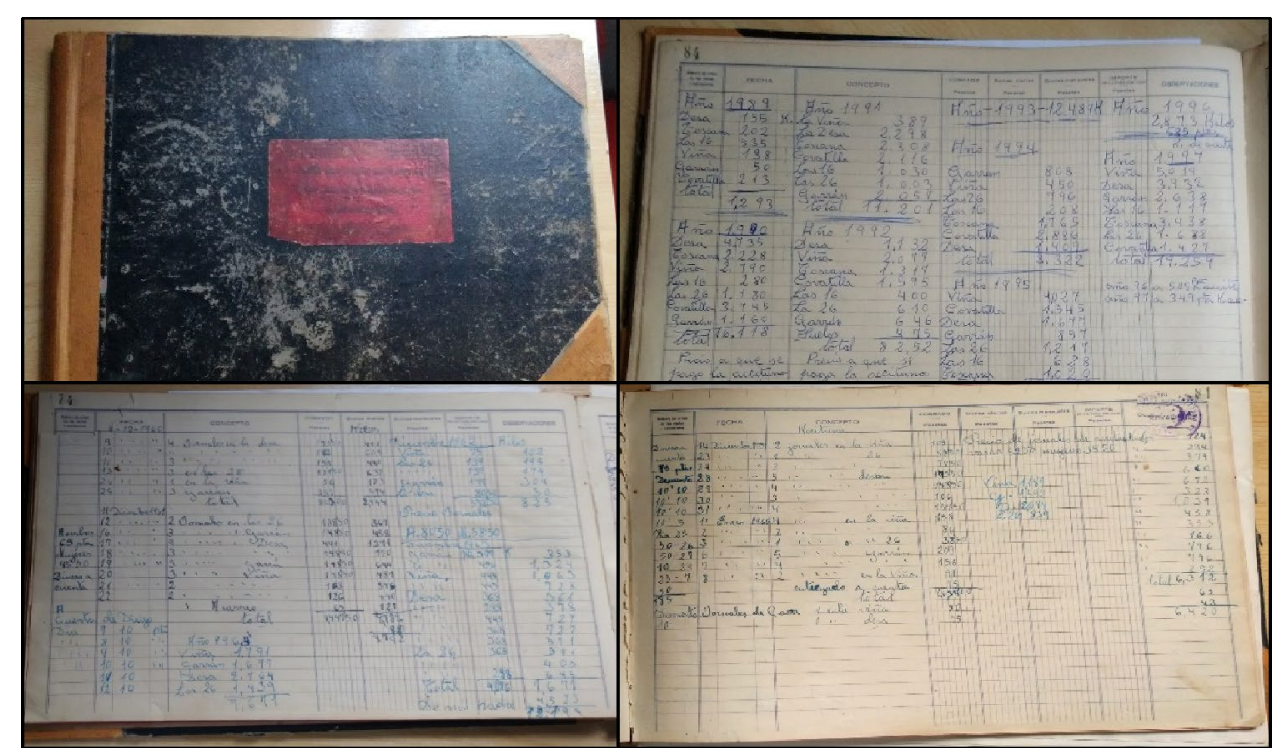

the months that drive high production and affect the whole rainy year, a principal component analysis (PCA) was conducted. Variables were centred and normalised, and a Kaiser-Meyer-Olkin (KMO) test of sphericity, the coefficients and the determinants were included. The PCA was performed using an orthogonal rotation method (Varimax) based on a standard correlation matrix.
Table 2 Data (total rainfall amount in $\mathrm{mm}$ ) from nearby climate stations that were used to fill gaps in the precipitation data series for Bailén

\begin{tabular}{llllr}
\hline Year & Month & Linares & Úbeda & Bailén \\
\hline 2000 & December & 107.6 & 111.6 & 115.16 \\
2004 & November & 2.4 & 6.2 & 3.99 \\
2004 & December & 47.8 & 40.8 & 47.14 \\
2007 & November & 65.6 & 41.6 & 54.38 \\
2007 & December & 5 & 4 & 4.8 \\
Average & November & 59 & 65 & - \\
& December & 67 & 87 & - \\
\hline
\end{tabular}




\section{Results and discussion}

\section{Calculation of gaps and description of the monthly rainfall regime in the municipality of Bailén}

The accurate analysis of rainfall data was impeded by the presence of gaps in the precipitation data series from stations set up to provide such data (Stooksbury et al. 1999). Table 2 presents data used in calculations performed to fill the gaps in the precipitation data series. In the case of the municipality of Bailén, data from the agroclimatic stations of Úbeda and Linares managed by the IFAPA were used because they met two essential conditions: (1) they provided data for the dates for which Bailén had gaps in its rainfall data series, and (2) the physiographic and climatic conditions at the Úbeda and Linares stations were similar to those in Bailén.

In Fig. 4, we can observe that the rainfall tends to be greatest in the autumn and winter months (October, December and January). In addition, the lowest rainfall occurs in the middle of spring, throughout the summer and in early September. The total annual rainfall is $532.3 \pm 173 \mathrm{~mm}$ on

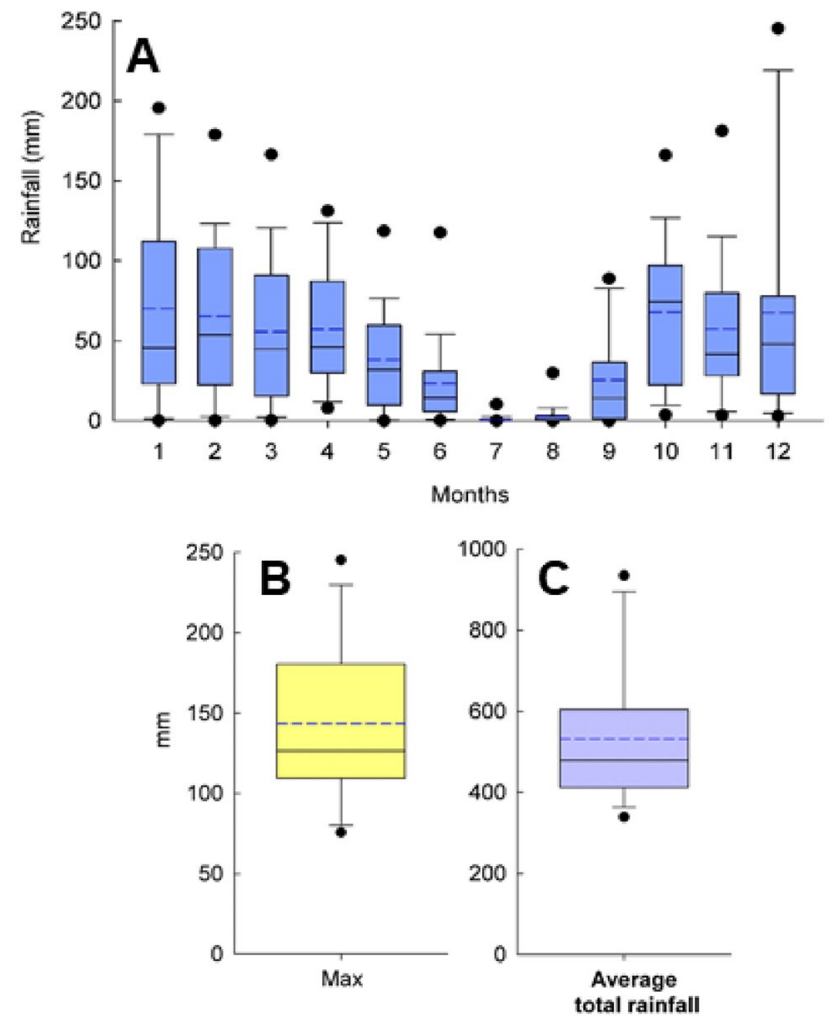

Fig. 4 Monthly rainfall (A), maximum monthly rainfall (B) and total average rainfall $(\mathbf{C})$. A dotted line represents an average value; a solid continuous line indicates a median value, and black circles represent the 5th and 95th percentiles average, and the estimated maximum monthly precipitation was $257 \mathrm{~mm}$ (in December 1995). The maximum annual rainfall exceeded $961 \mathrm{~mm}$ and the minimum was almost a fifth of this value ( $324 \mathrm{~mm}$ in 2005). These results illustrate the irregularity of climate data for the Mediterranean. They also highlight some interesting points to be made if we consider the rainfall to be a separate factor that influences the olive production in this area. Twenty-three percent of the months included in the dataset had rainfall of less than $3 \mathrm{~mm}$; most of those were summer months. Recurring drought periods can limit the recharge of soil water available for plants and living organisms, thus affecting food security and soil quality, as seen in other territories (Bot and Benites 2005). Knowing this, it could be possible to develop efficient tools to reduce the negative effects of drought and aid policymakers in their decisions (Parsons et al. 2019; West et al. 2019). Another important issue is that the soils tend to be bare during the rainiest period; therefore, using these data, farmers could determine when vegetative cover should be established and sown to best avoid water and nutrient competition (Novara et al. 2021).

\section{Total olive production and total rainfall in the study area}

Figure 5 depicts the olive production and rainfall during the two time intervals of interest. Neither the precipitation nor the total production follow a regular pattern if we consider annual values. In general, it seems that increases and decreases in production tend to coincide with those in rainfall. However, it is not possible to discern the overall trend in each parameter from this graph, or if it depended on a specific moment of the year. The average total production per year was $12,323.6 \mathrm{~kg}(\approx 1487.56 €)$, with the maximum total production of $27,006 \mathrm{~kg}$ occurring in 2005 (rainfall: $660 \mathrm{~mm}$ ), which yielded $1311 €$. The minimum total production, $548 \mathrm{~kg}$, occurred in 1974 (when the rainfall was only $363 \mathrm{~mm}$ ), which yielded 63€.

From these results, it is possible to identify the difficulties that a farmer could have in maintaining the minimum production needed to ensure food security for their family; such difficulties have also been reported for other least developed countries (Haghtalab et al. 2019; Kyei-Mensah et al. 2019). As shown by Coughlan de Perez et al. (2019), the results obtained from analyses of precipitation trends and agricultural production can be very useful for rural communities. Those authors pointed out that the utility of such analyses could also be improved by including seasonal forecasts to prevent possible outcomes that could lead to a higher risk of food insecurity in the future. We recognise that other key factors are also important for understanding the fluctuations in olive production over the years, such as soil properties and plant status. However, crop cultivatation without 


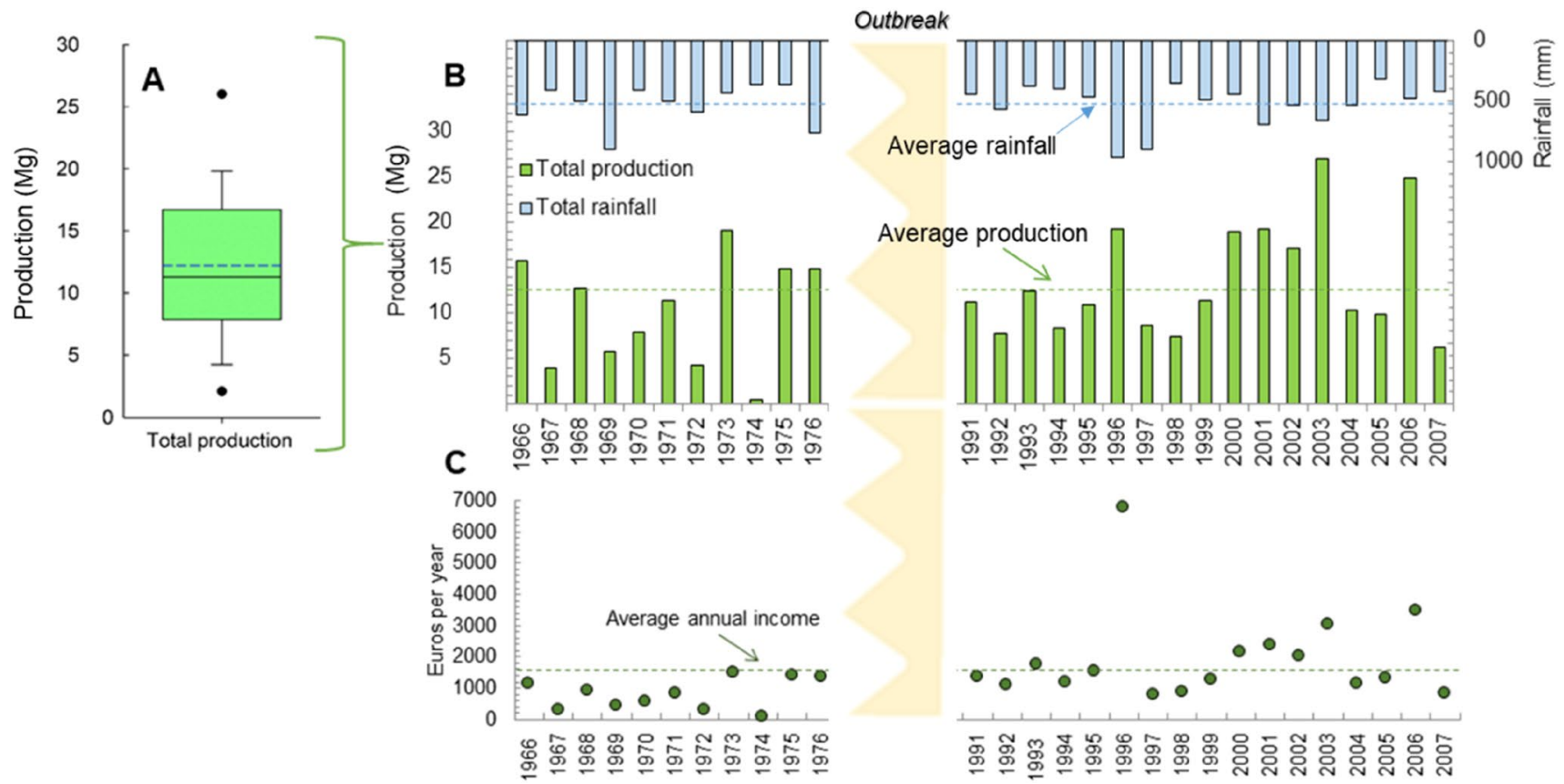

Fig. 5 Total olive production (A), total rainfall and production each year (B), and payment per kilogram of olives in euros $(\mathbf{C})$. A dotted line represents an average value; a solid continuous line indicates a median value, and black circles correspond to the 5th and 95th percentiles

irrigation-relying exclusively on total rainfall amount and rainfall intensity to provide all of the water required by the plants-is very risky. Such an approach makes the olive plantations studied in this work highly vulnerable to droughts, given the rainfall patterns observed for the study area.

Therefore, we can hypothesise that this problem could be very common in rainfed olive plantations across Jaén (the region that produces the most olive oil globally). In fact, this problem could become even worse given the expected increase in temperature due to global warming, as this warming could affect the plant phenology in this region (Galán et al. 2005; García-Mozo et al. 2006), making this region even more dependent on the water and subsidies available. This is a key reason to transform the rainfed plantations into irrigated ones.

\section{Correlation statistics and principal component analysis}

Finally, in Table 3 and Fig. 6, the correlations among the monthly average rainfall values, the total rainfall, and the total olive production are analysed using the bilateral Spearman's rank correlation coefficient and PCA. The results obtained must be interpreted taking into account the great variability of the Mediterranean climate and noting that the only factor that helps to determine the annual olive production and is integrated into the study is rainfall. However, as already noted above, other prominent factors also influence
Table 3 Spearman's rank correlation coefficients for pairwise correlations among the average rainfall for each month from January to December, the total average rainfall $(R)$, the total olive production $(P)$ and the average annual rainfall $(A)$

\begin{tabular}{lccl}
\hline Variable & $R$ & $P$ & $A$ \\
\hline Jan & 0.210 & 0.001 & -0.144 \\
Feb & 0.138 & -0.212 & -0.151 \\
Mar & 0.024 & 0.312 & -0.191 \\
Apr & 0.176 & -0.004 & -0.130 \\
May & -0.130 & 0.073 & 0.024 \\
Jun & -0.299 & -0.126 & -0.368 \\
Jul & 0.175 & 0.251 & $0.384^{*}$ \\
Aug & 0.346 & $0.449^{*}$ & 0.326 \\
Sep & 0.342 & 0.362 & $0.379^{*}$ \\
Oct & $0.467^{*}$ & 0.289 & 0.076 \\
Nov & $0.426^{*}$ & 0.144 & 0.018 \\
Dec & $0.403^{*}$ & $0.455^{*}$ & 0.315 \\
$R$ & 1.000 & 0.328 & $0.407^{*}$ \\
$P$ & 0.328 & 1.000 & 0.063 \\
$A$ & $0.407^{*}$ & 0.063 & 1.000 \\
\hline
\end{tabular}

Jan, Feb, Mar, ..., Dec are the average rainfall values for the corresponding months

* Correlation is significant at the $p<0.05$ level

olive production, such as temperature, soil type and mechanisation of olive production (Assefa et al. 2020; Iwasaki et al. 2020; Marques et al. 2020; Yazdanbakhsh et al. 2020). 


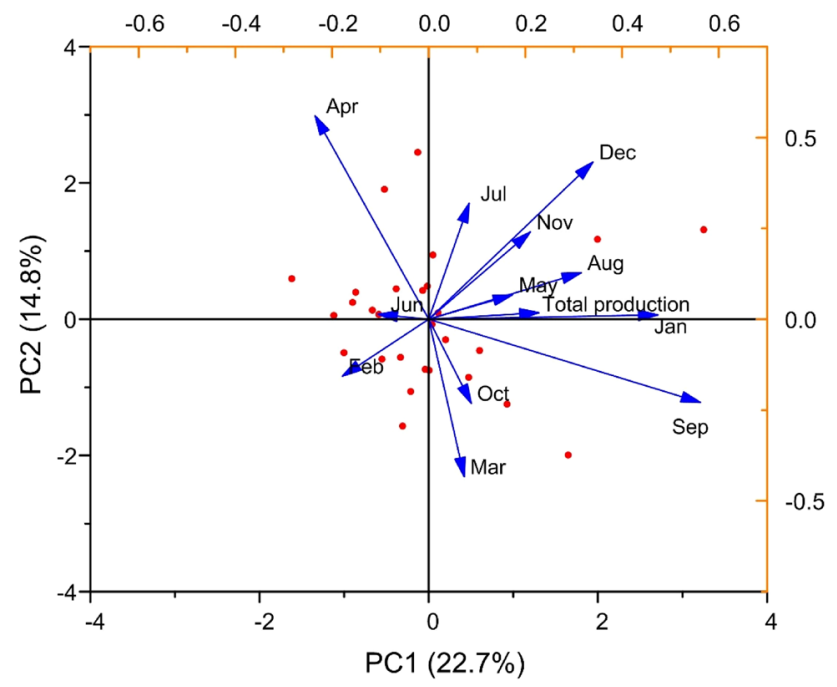

Fig. 6 Principal component (PC) analysis using monthly average and total olive production values

The dataset shows that the rainfall data series for the municipality of Bailén is highly irregular. Thus, taking into account the relationship between the total annual precipitation and production, some significant correlations were observed. Positive growth in the production of olives occurred when the rainfall was highest, in December (0.455) and August (0.499). In the PCA, we can also observe the effects of the driest months (July and August) and the wettest ones (November and December) on olive production. Also, the data for April and September can strongly affect the production for the whole year.

These results largely coincide with two key times for olive cultivation, as pointed out by Aguilera and Ruiz Valenzuela (2009): (1) flowering between May and July and (2) the end of the dry season and soil water recharge before the final ripening of the olives. Therefore, the discussion of these data is tempered by a clear biological and edaphic argument. If rainfall is high during the period in late spring and summer when the temperature is rising, the flowering of olive trees can be interrupted and affected. On the other hand, high rainfall in December could coincide with a greater recharge of soil water after the usual arid summer season. The dataset also shows another phenomenon related to the Mediterranean climate of this municipality. If rainfall is high during October (0.467), November (0.426) and December (0.403), the total annual rainfall may also be high, reducing climate aridity (Reiser and Kutiel 2010).

Knowledge of the seasonal pattern and spatial distribution of rainfall makes it easier to understand the ecosystem behaviour and easier for humans to manage these drylands. Furthermore, by extrapolating the results of this study to other areas with similar or different agroclimatic situations, this study could lead to new advances in our knowledge of the relationship between rainfall and production. Our results for this region are interesting because they relate interannual production to precipitation and address the issue of farmer income, which is directly related to production. The olive groves of interest here do not have irrigation systems and use manure as a fertiliser. In rainfed environments with a Mediterranean climate, the application of manure without irrigation water has only a limited effect on the availability of nutrients to the olives (Fernández-Hernández et al. 2014; Zipori et al. 2020). To release nutrients, the manure needs to be mineralised, and this process depends on microbial activity, which is also limited in the absence of moisture. For this reason, the present work would be even more beneficial if it were to include rainfed olive groves where mineral fertilisers are applied and to evaluate the effect of precipitation on olive yield. This analysis could demonstrate whether there is a yield benefit associated with the application of mineral fertilisers in a rainfed environment, as it could make nutrients available to plants more quickly and could make this study more valuable by providing useful advice to producers.

Another key point is related to weed control. Weeds are controlled through hand tillage each year, based on the advice of their ancestors, neighbours and the olive cooperative. In contrast to other systems, tillage damages the superficial roots of trees, which can reduce their capacity to absorb water and nutrients (Barneveld et al. 2009; Gómez et al. 1999; Turrini et al. 2017). Also, the olive trees will then need to use photoassimilates to reconstruct their roots during a period when those photoassimilates should be used to develop fruit. Two other issues could strongly compromise our data analysis: pruning and masting (Conde et al. 2008; Famiani et al. 2019; Tekaya et al. 2016). Pruning can damage trees and reduce their photosynthetic area; thus, in the year after the pruning is performed (especially if the pruning was severe), the olive trees invest in rearranging their photosynthetic structure, and this activity competes with fruit development. As pruning is performed yearly by the same farmer, this was not a key factor in our study, although it may have had an impact on some trees. Another important factor that could affect olive production is the alternate bearing (masting) typical of olive trees. For those reasons, to establish more accurate correlations, it is necessary to gather more reference data for this study.

\section{Farmer income is climate dependent: implications for sustainable agriculture}

Figure 7 shows the relation between rainfall and olive production, and the irregularity of the weather conditions. For rainfed agricultural land, the climatic conditions control the production, but this relationship is highly variable and we can see that it is not linear. The relationship between rainfall and olive production and thus the final income of the farmer 

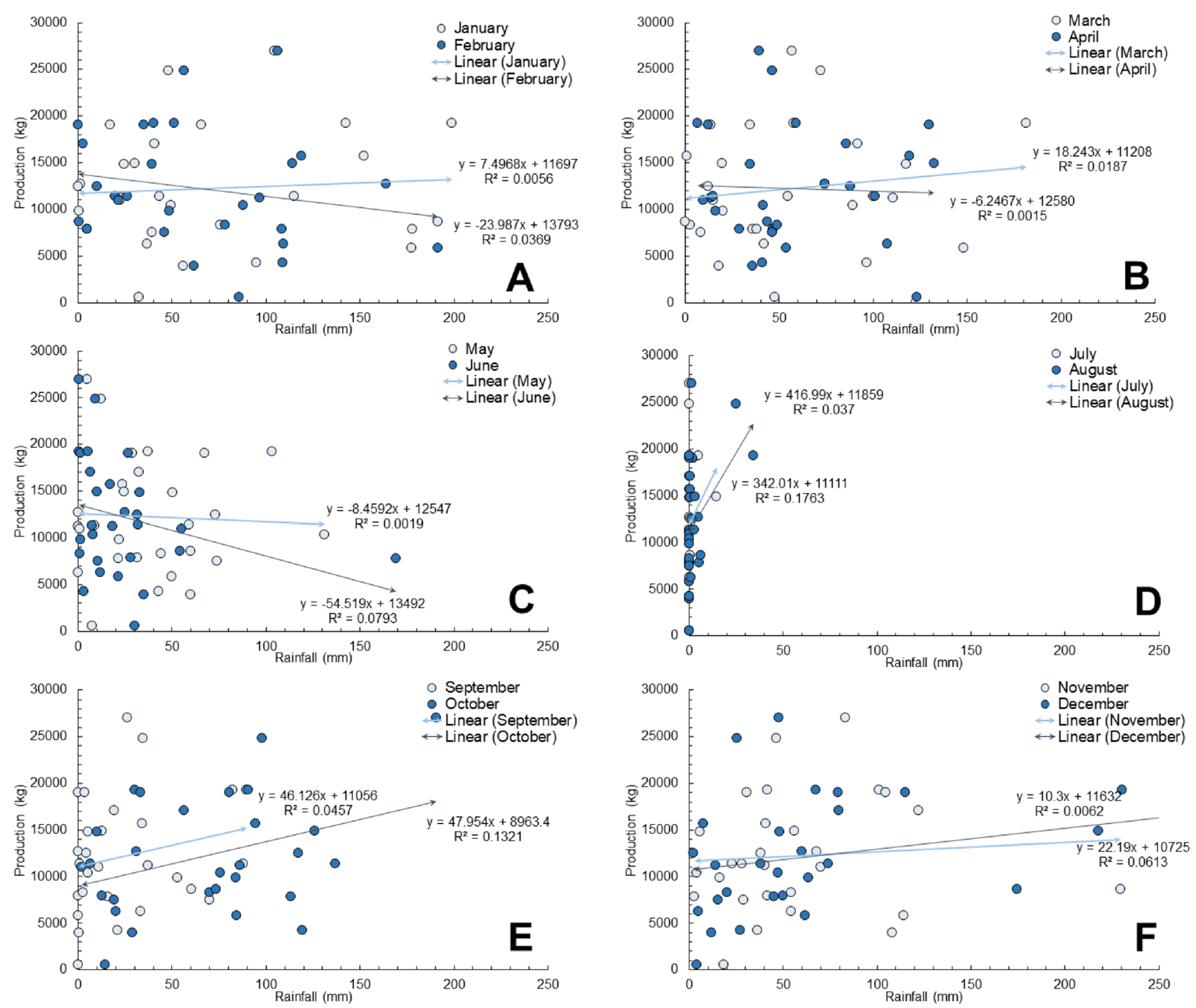

Fig. 7 Scatter plots of average monthly rainfall $(\mathrm{mm})$ versus olive production $(\mathrm{kg})$ for each month of the year; linear trends are also shown

is difficult to predict. Our findings for the province of Jaén show that traditional farming is highly dependent on the difficult climatic conditions in this area. Such a situation is also observed for rainfed agriculture in Africa, where traditional farmers need to adapt to weather changes and rainfall variability year after year (Muluneh et al. 2015; Thomas et al. 2007). Wherever it is performed around the world, agriculture needs to adapt to the local climatic conditions, but this is especially the case in traditional rainfed farming (Araya et al. 2010; Calzadilla et al. 2013; Kurukulasuriya et al. 2011). In Australia, where there are highly mechanised farms, several rainfed agricultural areas with maize plantations are successfully coping with climate variability (Birch et al. 2008). The availability of water is key to reducing the negative impacts of climate variability; for example, the advanced agriculture of Switzerland uses irrigation as an adaptation strategy (Finger et al. 2011).

We consider the key factor to be the rainfall, in terms of either the amount of rain, its seasonality, or drought recurrence (Rao et al. 2011). To adjust to changes in rainfall, farmers have to apply new and adapted strategies (Graef and Haigis 2001; Hiernaux et al. 2009). The changes in rainfall are related to changes in the world's climate, such as changes in its atmospheric composition, but are also due to local deforestation (Longobardi et al. 2016). In the last 50 years, the Green Revolution has resulted in the introduction of mechanisation (ploughing, herbicide and pesticide administration, tractors, and mechanical harvesting) to olive groves, which has increased production (Almonacid and Martínez 2018; Shiel 2018). Since the change in Spanish currency 
Table 5 Registered annual price of olive oil per kg during the period 2000-2007 according to data from the Bailén Agrarian Cooperative

\begin{tabular}{llllllll}
\hline Year & 2000 & 2001 & 2002 & 2003 & 2005 & 2006 & 2007 \\
\hline Price/kg $(€)$ & 2.61 & 2.49 & 2.13 & 2.79 & 2.96 & 2.67 & 2.6 \\
\hline
\end{tabular}

Data were obtained from a handwritten notebook relating to an olive field plantation belonging to Mr. Nicolás Linares

from pesetas to euros, the price of olive oil has fallen, as highlighted by data from the Bailén Agrarian Cooperative summarised in Table 5. In the present work, we have focused on a farm in Jaén where production was highly dependent on rainfall, resulting in highly variable production and therefore unpredictable income for the farmer's family. This is because the production was very low during some years (e.g. in 1975, production was $400 \mathrm{~kg}$ and income was $1401 €$ ).

The irregularity of the prices and elevated dependency on the weather conditions have led to two commonly encountered situations along the Mediterranean Belt (Serra et al. 2014): (1) some farmers have abandoned their lands (resulting in rural depopulation and the migration of young people away from rural areas), increasing landscape fragmentation; (2) other landowners have improved the production achieved by their farms, while monoculture has increased in importance. This second premise drastically reduces alternative solutions to fluctuations in global market prices (Vidal-Legaz et al. 2013) and specific issues such as illness (Hofmeister 1971) or drought periods (Cabezas et al. 2020). However, it can also be seen as the great capacity of olive groves to generate landscapes of great cultural value (Sánchez Martínez and Ortega Ruiz 2016). Rainfed agriculture such as this olive monoculture is under threat due to its low competitiveness, even though it provides a high-quality product that has a low impact on the ecosystem (Wani et al. 2009). However, rainfed agriculture is decreasing in many countries of the world due to its low production levels (Rockström et al. 2010; Sharma et al. 2017). Some authors claim that it could provide a pathway out of poverty, and that rainfed agriculture can directly promote household food security (Harris and Orr 2014). Therefore, to improve sustainability and stop land degradation in olive fields, it is necessary to develop specific strategies such as (1) reducing opportunity costs for the farmer's family, (2) enhancing parttime jobs for olive growers, and (3) helping to develop suitable and efficient irrigation systems or water-harvesting systems to collect the rain as well as efficient fertilisation plans based on the nutrient requirements of the crop (Duarte et al. 2008). Areal and Riesgo (2014) also recommend the provision of economic support and the implementation of efficient policies, mainly at the council level. Farmers' perceptions are also relevant to the impact of climate change on agricultural production because the utilisation of farmers' local knowledge could help to optimize the formal and (mainly) informal actions taken in response to climate aridity and drought; mitigative or adaptive actions can be generalised from a very local situation to broader contexts.

The research carried out here has demonstrated that farmer subsistence based on rainfed olive production is highly dependent on the local climatic conditions. To achieve sustainable farm management, it is necessary to adapt the production process so that it is sustainable, and the prices of olive-based products need to be sufficient to make it possible to achieve the sustainable development goals of the United Nations (Keesstra et al. 2018a; Visser et al. 2019). The soil system is another key factor in olive production, and proper soil management will contribute to achieving more resilient soils that can supply the required services even under arid climatic conditions. These issues are now being debated in Andalusia due to the large amount of olives produced in this region and the extensive area of land affected by olive production in Andalusia. GómezLimón et al. (2012) evaluated the eco-efficiency of olive farms in Andalusia and found that the most eco-efficient production system is the traditional plain growing system. However, our experience of the Bailén groves is that their olive production levels are very low, and the low market prices of olives and low amounts earned when the olives produced by the the Bailén groves are sold do not help to improve farmer income. We agree with Gómez-Limón et al. (2012), who demonstrated that the soil and the climate are the key determinants of the management. Similar findings were obtained by De Luca et al. (2018) in southern Italy, who claim that a holistic sustainability assessment is useful, especially if it involves relevant stakeholders. Recently, another pressure on olive groves - the urban sprawl - has begun to exert its influence. The main issue here is to achieve sustainability, and it is important to develop farm-scale approaches such as that we developed in Bailén or those developed by Tzouramani et al. (2020) in Greece and Palese et al. (2013) in Italy.

The new challenge for rainfed agriculture is to achieve sustainability through the use of organic farming, which will protect the soil, water and biota and bring higher wages to the farmers. This is relevant to all crops, including olives (Berg et al. 2018) and grapes (Rodrigo-Comino et al. 2020a, b; Cerdà and Rodrigo-Comino 2021). The management of organic matter is a key issue (Novara et al. 2019), as are government policies (Chabbi et al. 2017; Morris and Winter 1999). Moreover, the use of small plots is very important as it reduces the connectivity of flows (Cerdà et al. 2021a; Keesstra et al. 2018b) because each farm border acts as a soil erosion collector. This reduces the need to apply soil 
conservation strategies, which can represent a considerable extra expense for farmers (Cerdà et al. 2021b). The general trend in Mediterranean agriculture is to build large farms by merging small ones to achieve economic profits, but this risks environmental sustainability due to the increase in soil erosion caused by the increased runoff delivery resulting from more efficient flow connectivity (Cerdà and RodrigoComino 2020; Rodrigo-Comino et al. 2018a).

\section{Conclusions}

The results of this study indicate how changes in rainfall over time determine the total annual olive production. More specifically, the increase in rainfall observed in December and August coincided with a significant increase in the total olive production by weight. It is also worth highlighting the variability of Mediterranean rainfall trends and their influence, such that when a given year is rainy, the highest rainfall occurs during April, October, November and December. These findings indirectly highlight the difficulties faced by a farmer who has a small property, no irrigation system for their plot, and unmechanised production processes (a very common situation in Mediterranean olive groves across southern Europe), as the production and therefore income achieved by the farmer will then largely depend on whether sufficient rainfall occurs during certain time intervals as well as the subsidies available. We conclude that this investigation could help Mediterranean farmers to address the risks to water availability and food security of operating olive plantations without irrigation systems. In the future, this study will be enhanced by including other key factors in the correlation analysis, such as soil processes and management, temperature, and plant status, allowing us to verify the fluctuations in olive production over the years.

Acknowledgements We thank Rosa Oriola and Manuel Comino for the data they collected year after year, which are now being used as a dataset for scientific research. Both Rosa and Manuel-a farmer and his wife who are fully dependent on the agricultural production of their olive plantation to subsist-provided basic information that was used to research the variability in climate and olive production.

Open Access This article is licensed under a Creative Commons Attribution 4.0 International License, which permits use, sharing, adaptation, distribution and reproduction in any medium or format, as long as you give appropriate credit to the original author(s) and the source, provide a link to the Creative Commons licence, and indicate if changes were made. The images or other third party material in this article are included in the article's Creative Commons licence, unless indicated otherwise in a credit line to the material. If material is not included in the article's Creative Commons licence and your intended use is not permitted by statutory regulation or exceeds the permitted use, you will need to obtain permission directly from the copyright holder. To view a copy of this licence, visit http://creativecommons.org/licenses/by/4.0/.

\section{References}

Aguilar E, Auer I, Brunet M, Peterson TC, Wieringa J, Llansó P (2003) Guidelines on climate metadata and homogenization (WMO/TD no. 1186). World Meteorological Organization, Geneva

Aguilera F, Ruiz Valenzuela L (2009) Study of the floral phenology of Olea europaea L. in Jaén province (SE Spain) and its relation with pollen emission. Aerobiologia 25:217. https://doi.org/10. 1007/s 10453-009-9127-5

Almonacid G, Martínez S (2018) The rise of the Mediterranean woody crops in Southern Spain. Sci Technol Dev J Soc Sci Humanit 2:5-16. https://doi.org/10.32508/stdjssh.v2i1.473

Amate JI, de Molina MG, Vanwalleghem T, Fernández DS, Gómez JA (2013) Erosion in the Mediterranean: the case of olive groves in the South of Spain (1752-2000). Environ Hist 18:360-382. https://doi.org/10.1093/envhis/emt001

Araya A, Keesstra SD, Stroosnijder L (2010) A new agro-climatic classification for crop suitability zoning in northern semi-arid Ethiopia. Agric For Meteorol 150:1057-1064. https://doi.org/ 10.1016/j.agrformet.2010.04.003

Areal FJ, Riesgo L (2014) Farmers' views on the future of olive farming in Andalusia, Spain. Land Use Policy 36:543-553. https:// doi.org/10.1016/j.landusepol.2013.10.005

Arenas-Castro S, Gonçalves JF, Moreno M, Villar R (2020) Projected climate changes are expected to decrease the suitability and production of olive varieties in southern Spain. Sci Total Environ 709:136161. https://doi.org/10.1016/j.scitotenv.2019.136161

Ashenfelter O, Storchmann K (2010) Using hedonic models of solar radiation and weather to assess the economic effect of climate change: the case of Mosel Valley vineyards. Rev Econ Stat 92:333-349. https://doi.org/10.1162/rest.2010.11377

Assefa F, Elias E, Soromessa T, Ayele GT (2020) Effect of changes in land-use management practices on soil physicochemical properties in Kabe Watershed, Ethiopia. Air Soil Water Res 13:1178622120939587. https://doi.org/10.1177/1178622120 939587

Barneveld RJ, Bruggeman A, Sterk G, Turkelboom F (2009) Comparison of two methods for quantification of tillage erosion rates in olive orchards of north-west Syria. Soil Tillage Res 103:105-112

Benites J, Pisante M, Stagnari F (2005) Integrated soil and water management for orchard development: role and importance. In: Benites J, Pisante M, Stagnari F (eds) Proceedings of the international seminar "Integrated soil and water management for orchard development-role and importance." Food and Agriculture Organization, Rome

Benmehaia AM, Merniz N, Oulmane A (2020) Spatiotemporal analysis of rainfed cereal yields across the eastern high plateaus of Algeria: an exploratory investigation of the effects of weather factors. Euro-Mediterr J Environ Integr 5:54. https://doi.org/10. 1007/s41207-020-00191-x

Berg H, Maneas G, Salguero Engström A (2018) A comparison between organic and conventional olive farming in Messenia, Greece. Horticulturae 4:15. https://doi.org/10.3390/horticultu rae 4030015

Birch CJ, Stephen K, McLean G, Doherty A, Hammer GL, Robertson MJ (2008) Reliability of production of quick to medium maturity maize in areas of variable rainfall in north-east Australia. Aust J Exp Agric 48:326-334. https://doi.org/10.1071/EA06104

Bot A, Benites J (2005) The importance of soil organic matter: key to drought-resistant soil and sustained food production. Food and Agriculture Organization, Rome

Braudel F (1996) The Mediterranean and the Mediterranean World in the age of Philip II, vol 1. University of California Press, Berkeley 
Cabezas JM, Ruiz-Ramos M, Soriano MA, Gabaldón-Leal C, Santos C, Lorite IJ (2020) Identifying adaptation strategies to climate change for Mediterranean olive orchards using impact response surfaces. Agric Syst 185:102937. https://doi.org/10.1016/j.agsy. 2020.102937

Calzadilla A, Zhu T, Rehdanz K, Tol RSJ, Ringler C (2013) Economywide impacts of climate change on agriculture in Sub-Saharan Africa. Ecol Econ 93:150-165. https://doi.org/10.1016/j.ecole con.2013.05.006

Cerdà A, Rodrigo-Comino $\mathrm{J}$ (2020) Is the hillslope position relevant for runoff and soil loss activation under high rainfall conditions in vineyards? Ecohydrol Hydrobiol 20:59-72. https://doi.org/10. 1016/j.ecohyd.2019.05.006

Cerdà A, Rodrigo-Comino J (2021) Regional farmers' perception and societal issues in vineyards affected by high erosion rates. Land 10:205. https://doi.org/10.3390/land10020205

Cerdà A, Daliakopoulos IN, Terol E, Novara A, Fatahi Y, Moradi E, Salvati L, Pulido M (2021a) Long-term monitoring of soil bulk density and erosion rates in two Prunus persica (L.) plantations under flood irrigation and glyphosate herbicide treatment in $\mathrm{La}$ Ribera District, Spain. J Environ Manag 282:111965. https://doi. org/10.1016/j.jenvman.2021.111965

Cerdà A, Novara A, Dlapa P, López-Vicente M, Úbeda X, Popović Z, Mekonnen M, Terol E, Janizadeh S, Mbarki S, Saldanha-Vogelmann E, Hazrati S, Sannigrahi S, Parhizkar M, Giménez-Morera A (2021b) Rainfall and water yield in Macizo del Caroig, Eastern Iberian Peninsula. Event runoff at plot scale during a rare flash flood at the Barranco de Benacancil. Cuad Investig Geogr 47:95-119. https://doi.org/10.18172/cig.4833

Chabbi A, Lehmann J, Ciais P, Loescher HW, Cotrufo MF, Don A, SanClements M, Schipper L, Six J, Smith P, Rumpel C (2017) Aligning agriculture and climate policy. Nat Clim Change 7:307-309. https://doi.org/10.1038/nclimate3286

Cicatelli A, Fortunati T, De Feis I, Castiglione S (2013) Oil composition and genetic biodiversity of ancient and new olive (Olea europea L.) varieties and accessions of southern Italy. Plant Sci 210:82-92. https://doi.org/10.1016/j.plantsci.2013.05.011

Conde C, Delrot S, Gerós H (2008) Physiological, biochemical and molecular changes occurring during olive development and ripening. J Plant Physiol 165:1545-1562. https://doi.org/10. 1016/j.jplph.2008.04.018

Coughlan de Perez E, van Aalst M, Choularton R, van den Hurk B, Mason S, Nissan H, Schwager S (2019) From rain to famine: assessing the utility of rainfall observations and seasonal forecasts to anticipate food insecurity in East Africa. Food Sec 11:57-68. https://doi.org/10.1007/s12571-018-00885-9

De Luca AI, Falcone G, Stillitano T, Iofrida N, Strano A, Gulisano G (2018) Evaluation of sustainable innovations in olive growing systems: a life cycle sustainability assessment case study in southern Italy. J Clean Prod 171:1187-1202. https://doi.org/ 10.1016/j.jclepro.2017.10.119

Delgado B, Ojeda JF, Amate JI, Andreu C (2013) Los olivares andaluces y sus paisajes distintivos del mundo mediterráneo. Rev Estud Reg 96:267-291

Duarte F, Jones N, Fleskens L (2008) Traditional olive orchards on sloping land: sustainability or abandonment? J Environ Manag 89:86-98. https://doi.org/10.1016/j.jenvman.2007.05.024

Emmanouilides C, Fousekis P, Grigoriadis V (2013) Price dependence in the principal EU olive oil markets. Span J Agric Res 12:3. https://doi.org/10.5424/sjar/2014121-4606

Famiani F, Farinelli D, Gardi T, Rosati A (2019) The cost of flowering in olive (Olea europaea L.). Sci Hortic 252:268-273. https://doi.org/10.1016/j.scienta.2019.03.008

Fernández-Hernández A, Roig A, Serramiá N, Civantos CG-O, Sánchez-Monedero MA (2014) Application of compost of twophase olive mill waste on olive grove: effects on soil, olive fruit and olive oil quality. Waste Manag 34:1139-1147. https://doi. org/10.1016/j.wasman.2014.03.027

Finger R, Hediger W, Schmid S (2011) Irrigation as adaptation strategy to climate change-a biophysical and economic appraisal for Swiss maize production. Clim Change 105:509-528. https://doi.org/10.1007/s10584-010-9931-5

Fraga H, Pinto JG, Santos JA (2019) Climate change projections for chilling and heat forcing conditions in European vineyards and olive orchards: a multi-model assessment. Clim Change 152:179-193. https://doi.org/10.1007/s10584-018-2337-5

Fraga H, Pinto JG, Viola F, Santos JA (2020) Climate change projections for olive yields in the Mediterranean Basin. Int J Climatol 40:769-781. https://doi.org/10.1002/joc.6237

Galán C, García-Mozo H, Vázquez L, Ruiz L, de la Guardia CD, Trigo MM (2005) Heat requirement for the onset of the Olea europaea L. pollen season in several sites in Andalusia and the effect of the expected future climate change. Int J Biometeorol 49:184-188. https://doi.org/10.1007/s00484-004-0223-5

García-Mozo H, Galán C, Jato V, Belmonte J (2006) Quercus pollen season dynamics in the Iberian peninsula: response to meteorological parameters and possible consequences of climate change. Ann Agric Environ Med 13:209-224

Gimeno E, Fitó M, Lamuela-Raventós RM, Castellote AI, Covas M, Farré M, de la Torre-Boronat M, López-Sabater MC (2002) Effect of ingestion of virgin olive oil on human low-density lipoprotein composition. Eur J Clin Nutr 56:114-120. https:// doi.org/10.1038/sj.ejcn.1601293

Gómez JA, Giráldez JV, Pastor M, Fereres E (1999) Effects of tillage method on soil physical properties, infiltration and yield in an olive orchard. Soil Tillage Res 52:167-175. https://doi.org/10. 1016/S0167-1987(99)00078-1

Gómez-Limón JA, Picazo-Tadeo AJ, Reig-Martínez E (2012) Eco-efficiency assessment of olive farms in Andalusia. Land Use Policy 29:395-406. https://doi.org/10.1016/j.landusepol.2011.08.004

Graef F, Haigis J (2001) Spatial and temporal rainfall variability in the Sahel and its effects on farmers' management strategies. J Arid Environ 48:221-231. https://doi.org/10.1006/jare.2000. 0747

Haghtalab N, Moore N, Ngongondo C (2019) Spatio-temporal analysis of rainfall variability and seasonality in Malawi. Reg Environ Change 19:2041-2054. https://doi.org/10.1007/ s10113-019-01535-2

Harris D, Orr A (2014) Is rainfed agriculture really a pathway from poverty? Agric Syst 123:84-96. https://doi.org/10.1016/j.agsy. 2013.09.005

Hiernaux P, Ayantunde A, Kalilou A, Mougin E, Gérard B, Baup F, Grippa M, Djaby B (2009) Trends in productivity of crops, fallow and rangelands in Southwest Niger: impact of land use, management and variable rainfall. J Hydrol 375:65-77. https://doi. org/10.1016/j.jhydrol.2009.01.032

Hofmeister B (1971) Four types of agriculture with predominant olive growing in Southern Spain-a case study. Geoforum 2:15-30. https://doi.org/10.1016/0016-7185(71)90027-3

Incerti G, Feoli E, Salvati L, Brunetti A, Giovacchini A (2007) Analysis of bioclimatic time series and their neural network-based classification to characterise drought risk patterns in South Italy. Int J Biometeorol 51:253-263. https://doi.org/10.1007/ s00484-006-0071-6

Infante-Amate J, de Molina MG (2013) The socio-ecological transition on a crop scale: the case of olive orchards in Southern Spain (1750-2000). Hum Ecol 41:961-969. https://doi.org/10.1007/ s10745-013-9618-4

Iwasaki E, Elbeih S, Shalaby A, Khedr H, Zaghloul ES (2020) Wells and land use changes in Dakhla Oasis (Egypt) using geospatial analysis: case study of Rashda village. Euro-Mediterr J Environ Integr 5:61. https://doi.org/10.1007/s41207-020-00202-x 
Jiménez EA, Simón VJG, Martínez JDS (2002) El olivar regado en la provincia de Jaén. Investig Geogr 0:5-32. https://doi.org/10. 14198/INGEO2002.28.03

Kairis O, Karavitis C, Kounalaki A, Salvati L, Kosmas C (2013) The effect of land management practices on soil erosion and land desertification in an olive grove. Soil Use Manag 29:597-606. https://doi.org/10.1111/sum.12074

Kairis O, Karavitis C, Salvati L, Kounalaki A, Kosmas K (2015) Exploring the impact of overgrazing on soil erosion and land degradation in a dry Mediterranean agro-forest landscape (Crete, Greece). Arid Land Res Manag 29:360-374. https://doi.org/10. 1080/15324982.2014.968691

Karamesouti M, Detsis V, Kounalaki A, Vasiliou P, Salvati L, Kosmas C (2015) Land-use and land degradation processes affecting soil resources: evidence from a traditional Mediterranean cropland (Greece). CATENA 132:45-55. https://doi.org/10.1016/j.catena. 2015.04.010

Keesstra S, Mol G, De Leeuw J, Okx J, Molenaar C, De Cleen M, Visser S (2018a) Soil-related sustainable development goals: four concepts to make land degradation neutrality and restoration work. Land 7:133. https://doi.org/10.3390/land7040133

Keesstra S, Nunes JP, Saco P, Parsons T, Poeppl R, Masselink R, Cerdà A (2018b) The way forward: can connectivity be useful to design better measuring and modelling schemes for water and sediment dynamics? Sci Total Environ 644:1557-1572. https://doi.org/10. 1016/j.scitotenv.2018.06.342

Kosmas C, Karamesouti M, Kounalaki K, Detsis V, Vassiliou P, Salvati L (2016) Land degradation and long-term changes in agropastoral systems: an empirical analysis of ecological resilience in Asteroussia-Crete (Greece). CATENA 147:196-204. https:// doi.org/10.1016/j.catena.2016.07.018

Kurukulasuriya P, Kala N, Mendelsohn R (2011) Adaptation and climate change impacts: a structural Ricardian model of irrigation and farm income in Africa. Clim Change Econ 02:149-174. https://doi.org/10.1142/S2010007811000255

Kyei-Mensah C, Kyerematen R, Adu-Acheampong S (2019) Impact of rainfall variability on crop production within the Worobong Ecological Area of Fanteakwa District, Ghana. Adv Agric. https:// doi.org/10.1155/2019/7930127

Longobardi P, Montenegro A, Beltrami H, Eby M (2016) Deforestation induced climate change: effects of spatial scale. PLoS ONE 11:1-34. https://doi.org/10.1371/journal.pone.0153357

López-Vicente M, Álvarez S (2018) Stability and patterns of topsoil water content in rainfed vineyards, olive groves, and cereal fields under different soil and tillage conditions. Agric Water Manag 201:167-176. https://doi.org/10.1016/j.agwat.2018.02.004

Marin C, Ramirez R, Delgado-Lista J, Yubero-Serrano EM, PerezMartinez P, Carracedo J, Garcia-Rios A, Rodriguez F, Gutierrez-Mariscal FM, Gomez P, Perez-Jimenez F, Lopez-Miranda J (2011) Mediterranean diet reduces endothelial damage and improves the regenerative capacity of endothelium. Am J Clin Nutr 93:267-274. https://doi.org/10.3945/ajcn.110.006866

Marques M, Ruiz-Colmenero M, Bienes R, García-Díaz A, Sastre B (2020) Effects of a permanent soil cover on water dynamics and wine characteristics in a steep vineyard in the Central Spain. Air Soil Water Res 13:1178622120948069. https://doi.org/10.1177/ 1178622120948069

Martínez JDS, Simón VJG (2011) La nueva reconversión productiva del olivar jiennense: aproximación inicial a sus fundamentos y limitaciones. Cuad Geogr Univ Granada 49:95-121. https://doi. org/10.30827/cuadgeo.v49i0.567

Michalopoulos G, Kasapi KA, Koubouris G, Psarras G, Arampatzis G, Hatzigiannakis E, Kavvadias V, Xiloyannis C, Montanaro G, Malliaraki S, Angelaki A, Manolaraki C, Giakoumaki G, Reppas S, Kourgialas N, Kokkinos G (2020) Adaptation of Mediterranean olive groves to climate change through sustainable cultivation practices. Climate 8:54. https://doi.org/10.3390/cli80 40054

Morris C, Winter M (1999) Integrated farming systems: the third way for European agriculture? Land Use Policy 16:193-205

Muluneh A, Biazin B, Stroosnijder L, Bewket W, Keesstra SD (2015) Impact of predicted changes in rainfall and atmospheric carbon dioxide on maize and wheat yields in the Central Rift Valley of Ethiopia. Reg Environ Change 15:1105-1119

Naredo JM (1983) La crisis del olivar como cultivo "biológico" tradicional. Agric Soc 26:167-288

Novara A, Pulido M, Rodrigo-Comino J, Prima SD, Smith P, Gristina L, Gimenez-Morera A, Terol E, Salesa D, Keesstra S (2019) Long-term organic farming on a citrus plantation results in soil organic carbon recovery. Cuad Investig Geogr 45:271-286. https://doi.org/10.18172/cig.3794

Novara A, Cerda A, Barone E, Gristina L (2021) Cover crop management and water conservation in vineyard and olive orchards. Soil Tillage Res 208:104896. https://doi.org/10.1016/j.still.2020. 104896

Oteros J, Orlandi F, García-Mozo H, Aguilera F, Dhiab AB, Bonofiglio T, Abichou M, Ruiz-Valenzuela L, del Trigo MM, Díaz de la Guardia C, Domínguez-Vilches E, Msallem M, Fornaciari M, Galán C (2014) Better prediction of Mediterranean olive production using pollen-based models. Agron Sustain Dev 34:685-694. https://doi.org/10.1007/s13593-013-0198-x

Palese AM, Pergola M, Favia M, Xiloyannis C, Celano G (2013) A sustainable model for the management of olive orchards located in semi-arid marginal areas: some remarks and indications for policy makers. Environ Sci Policy 27:81-90. https://doi.org/10. 1016/j.envsci.2012.11.001

Parsons DJ, Rey D, Tanguy M, Holman IP (2019) Regional variations in the link between drought indices and reported agricultural impacts of drought. Agric Syst 173:119-129. https://doi. org/10.1016/j.agsy.2019.02.015

Perujo Villanueva M, Colombo S (2017) Cost analysis of parcel fragmentation in agriculture: the case of traditional olive cultivation. Biosyst Eng 164:135-146. https://doi.org/10.1016/j. biosystemseng.2017.10.003

Ponti L, Gutierrez AP, Ruti PM, Dell'Aquila A (2014) Fine-scale ecological and economic assessment of climate change on olive in the Mediterranean Basin reveals winners and losers. PNAS 111:5598-5603. https://doi.org/10.1073/pnas.1314437111

Rao KPC, Ndegwa WG, Kizito K, Oyoo A (2011) Climate variability and change: farmer perceptions and understanding of intraseasonal variability in rainfall and associated risk in semi-arid Kenya. Exp Agric 47:267-291. https://doi.org/10.1017/S0014 479710000918

Reiser H, Kutiel H (2010) Rainfall uncertainty in the Mediterranean: dryness distribution. Theor Appl Climatol 100:123-135. https://doi.org/10.1007/s00704-009-0163-4

Rocamora-Montiel B, Glenk K, Colombo S (2014) Territorial management contracts as a tool to enhance the sustainability of sloping and mountainous olive orchards: evidence from a case study in Southern Spain. Land Use Policy 41:313-324. https:// doi.org/10.1016/j.landusepol.2014.06.016

Rockström J, Karlberg L, Wani SP, Barron J, Hatibu N, Oweis T, Bruggeman A, Farahani J, Qiang Z (2010) Managing water in rainfed agriculture - the need for a paradigm shift. Agric Water Manag Compr Assess Water Manag Agric 97:543-550. https:// doi.org/10.1016/j.agwat.2009.09.009

Rodrigo-Comino J, Keesstra SD, Cerdà A (2018a) Connectivity assessment in Mediterranean vineyards using improved stock unearthing method, LiDAR and soil erosion field surveys. Earth Surf Proc Land 43:2193-2206. https://doi.org/10.1002/esp.4385

Rodrigo-Comino J, Taguas E, Seeger M, Ries JB (2018b) Quantification of soil and water losses in an extensive olive orchard 
catchment in Southern Spain. J Hydrol 556:749-758. https://doi. org/10.1016/j.jhydrol.2017.12.014

Rodrigo-Comino J, Giménez-Morera A, Panagos P, Pourghasemi HR, Pulido M, Cerdà A (2020a) The potential of straw mulch as a nature-based solution for soil erosion in olive plantation treated with glyphosate: a biophysical and socioeconomic assessment. Land Degrad Dev 31:1877-1889. https://doi.org/10.1002/ldr.3305

Rodrigo-Comino J, Terol E, Mora G, Gimenez-Morera A, Cerdà A (2020b) Vicia sativa Roth. can reduce soil and water losses in recently planted vineyards (Vitis vinifera $\mathrm{L}$ ). Earth Syst Environ. https://doi.org/10.1007/s41748-020-00191-5 (in press)

Rodrigo-Comino J, Salvia R, Quaranta G, Cudlín P, Salvati L, Gimenez-Morera A (2021) Climate aridity and the geographical shift of olive trees in a Mediterranean Northern Region. Climate 9:64. https://doi.org/10.3390/cli9040064

Salmoral G, Willaarts BA, Garrido A, Guse B (2017) Fostering integrated land and water management approaches: evaluating the water footprint of a Mediterranean basin under different agricultural land use scenarios. Land Use Policy 61:24-39. https://doi. org/10.1016/j.landusepol.2016.09.027

Salvati L, Perini L, Sabbi A, Bajocco S (2012) Climate aridity and land use changes: a regional-scale analysis. Geogr Res 50:193-203. https://doi.org/10.1111/j.1745-5871.2011.00723.x

Sánchez Martínez JD, Ortega Ruiz A (2016) The olive monoculture of Jaen: historical structure, heritage values and cultural-touristic importance. Cuad Turismo 37:377-538

Sastre B, Barbero-Sierra C, Bienes R, Marques MJ, García-Díaz A (2016) Soil loss in an olive grove in Central Spain under cover crops and tillage treatments, and farmer perceptions. J Soils Sediments. https://doi.org/10.1007/s11368-016-1589-9

Scarascia MEV, Battista FD, Salvati L (2006) Water resources in Italy: availability and agricultural uses. Irrig Drain 55:115-127. https:// doi.org/10.1002/ird.222

Scheidel A, Krausmann F (2011) Diet, trade and land use: a socioecological analysis of the transformation of the olive oil system. Land Use Policy 28:47-56. https://doi.org/10.1016/j.landusepol. 2010.04.008

Serra P, Vera A, Tulla AF, Salvati L (2014) Beyond urban-rural dichotomy: exploring socioeconomic and land-use processes of change in Spain (1991-2011). Appl Geogr 55:71-81. https://doi.org/10. 1016/j.apgeog.2014.09.005

Sharma NK, Singh RJ, Mandal D, Kumar A, Alam NM, Keesstra S (2017) Increasing farmer's income and reducing soil erosion using intercropping in rainfed maize-wheat rotation of Himalaya, India. Agric Ecosyst Environ 247:43-53. https://doi.org/ 10.1016/j.agee.2017.06.026

Shiel RS (2018) Agricultural systems research. In: Callan H, Coleman $\mathrm{S}$ (eds) The international encyclopedia of anthropology. Wiley, Chichester, pp 1-6. https://doi.org/10.1002/9781118924396. wbiea1992

Stooksbury DE, Idso CD, Hubbard KG (1999) The effects of data gaps on the calculated monthly mean maximum and minimum temperatures in the continental United States: a spatial and temporal study. J Clim 12:1524-1533. https://doi.org/10.1175/15200442(1999)012\%3c1524:TEODGO\%3e2.0.CO;2

Storchmann K (2005) English weather and Rhine wine quality: an ordered probit model. J Wine Res 16:105-120. https://doi.org/ $10.1080 / 09571260500327648$

Taguas EV, Gómez JA (2015) Vulnerability of olive orchards under the current CAP (Common Agricultural Policy) regulations on soil erosion: a study case in Southern Spain. Land Use Policy 42:683-694. https://doi.org/10.1016/j.landusepol.2014.09.001

Taguas EV, Guzmán E, Guzmán G, Vanwalleghem T, Gómez JA (2015) Characteristics and importance of rill and gully erosion: a case study in a small catchment of a marginal olive grove. Cuad Investig Geogr 41:107-126. https://doi.org/10.18172/cig.2644
Tanasijevic L, Todorovic M, Pereira LS, Pizzigalli C, Lionello P (2014) Impacts of climate change on olive crop evapotranspiration and irrigation requirements in the Mediterranean region. Agric Water Manag 144:54-68. https://doi.org/10.1016/j.agwat.2014.05.019

Tekaya M, El-Gharbi S, Mechri B, Chehab H, Bchir A, Chraief I, Ayachi M, Boujnah D, Attia F, Hammami M (2016) Improving performance of olive trees by the enhancement of key physiological parameters of olive leaves in response to foliar fertilization. Acta Physiol Plant 38:101. https://doi.org/10.1007/ s11738-016-2122-x

Thomas DSG, Twyman C, Osbahr H, Hewitson B (2007) Adaptation to climate change and variability: farmer responses to intra-seasonal precipitation trends in South Africa. Clim Change 83:301-322. https://doi.org/10.1007/s10584-006-9205-4

Turrini A, Caruso G, Avio L, Gennai C, Palla M, Agnolucci M, Tomei PE, Giovannetti M, Gucci R (2017) Protective green cover enhances soil respiration and native mycorrhizal potential compared with soil tillage in a high-density olive orchard in a long term study. Appl Soil Ecol 116:70-78. https://doi.org/10.1016/j. apsoil.2017.04.001

Tzouramani I, Mantziaris S, Karanikolas P (2020) Assessing sustainability performance at the farm level: examples from Greek agricultural systems. Sustainability 12:1-22

Urhausen S, Brienen S, Kapala A, Simmer C (2011) Climatic conditions and their impact on viticulture in the Upper Moselle region. Clim Change 109:349-373. https://doi.org/10.1007/ s10584-011-0059-z

Vanwalleghem T, Amate JI, de Molina MG, Fernández DS, Gómez JA (2011) Quantifying the effect of historical soil management on soil erosion rates in Mediterranean olive orchards. Agr Ecosyst Environ 142:341-351. https://doi.org/10.1016/j.agee.2011.06.003

Vidal-Legaz B, Martínez-Fernández J, Picón AS, Pugnaire FI (2013) Trade-offs between maintenance of ecosystem services and socioeconomic development in rural mountainous communities in southern Spain: a dynamic simulation approach. J Environ Manag 131:280-297. https://doi.org/10.1016/j.jenvman.2013.09.036

Villalobos O, Mateos (1995) Nondestructive measurements of leaf area index in olive (Olea europaea L.) trees using a gap inversion method. Agric For Meteorol 73:29-42

Visser S, Keesstra S, Maas G, de Cleen M, Molenaar C (2019) Soil as a basis to create enabling conditions for transitions towards sustainable land management as a key to achieve the SDGs by 2030 . Sustainability 11:6792. https://doi.org/10.3390/su11236792

Wani SP, Rockström J, Oweis TY (2009) Rainfed agriculture: unlocking the potential. CABI, Wallingford

West H, Quinn N, Horswell M (2019) Remote sensing for drought monitoring and impact assessment: progress, past challenges and future opportunities. Remote Sens Environ 232:111291. https:// doi.org/10.1016/j.rse.2019.111291

Yazdanbakhsh A, Alavi SN, Valadabadi SA, Karimi F, Karimi Z (2020) Heavy metals uptake of salty soils by ornamental sunflower, using cow manure and biosolids: a case study in Alborz city, Iran. Air Soil Water Res 13:1178622119898460. https://doi.org/ $10.1177 / 1178622119898460$

Yu Y, Loiskandl W, Kaul H-P, Himmelbauer M, Wei W, Chen L, Bodner G (2016) Estimation of runoff mitigation by morphologically different cover crop root systems. J Hydrol 538:667-676. https:// doi.org/10.1016/j.jhydrol.2016.04.060

Zema DA, Denisi P, Taguas Ruiz EV, Gómez JA, Bombino G, Fortugno D (2015) Evaluation of surface runoff prediction by AnnAGNPS model in a large Mediterranean watershed covered by olive groves. Land Degrad Dev 27:811-822. https://doi.org/10.1002/ ldr.2390

Zipori I, Erel R, Yermiyahu U, Ben-Gal A, Dag A (2020) Sustainable management of olive orchard nutrition: a review. Agriculture 10:11. https://doi.org/10.3390/agriculture10010011 